\title{
Gas and Poetry: Humphry Davy in Bristol, 1798-1801
}

Frank A.J.L. James

University College London*

\section{http://orcid.org/0000-0002-0499-9291}

This paper is a contribution, historically grounded, to current discussions about how best to understand the relations of science and literature as cultural and social practices. It examines, in some detail, Humphry Davy's activities during the two and a half years, from the autumn of 1798 to the spring of 1801, that he worked at Thomas Beddoes's Medical Pneumatic Institution in Bristol. The loose and everchanging circle of creative individuals who formed around Beddoes and his Institution involved a formidable array of savants including members of the Watt and Wedgwood families as well as Romantics such as Southey, Coleridge and Wordsworth. The micro-chronological approach adopted here reveals the importance of print culture and sociability in the production of texts and knowledge, as well as the striking number and variety of projects proposed by the circle that never came to fruition. Nevertheless, those successful projects, such as Davy's work on nitrous oxide and the second edition of Wordsworth's Lyrical Ballads, contributed to making this period one of the key moments in English cultural history.

Keywords: Humphry Davy, Thomas Beddoes, Robert Southey, Samuel Taylor Coleridge, William Wordsworth, Bristol, the Medical Pneumatic Institution, Jacobin Politics, Nitrous

\footnotetext{
* Department of Science and Technology Studies, University College London, Gower Street, London, WC1E 6BT, England; The Royal Institution, 21 Albemarle Street, London, W1S 4BS, England. E-mail: fjames@ri.ac.uk. An earlier version of this paper was presented at the "Robert Southey and Romantic-era literature, culture and science: 1797, 1817, a Bicentennial Conference" held during April 2016 in Clifton. I am grateful for the comments that I received there and from Dahlia Porter and Tim Fulford on an earlier version of this paper. I thank the following archives for permission to study manuscripts and other documents in their collections: The Royal Institution (RI), Library of Birmingham (LoB), Cornwall Record Office (CRO), Wedgwood Museum (WM), Yale University Library (YUL), The National Archives (TNA), American Philosophical Society (APS), The Science Museum (SM), Carlisle Central Library (CCL), the National Library of Ireland, Edinburgh University Library, Karpeles Manuscript Library Museums, Dartmouth College, Morgan Library and Museum, the Natural History Museum, the Royal Society of London and the Linnean Society. Letters written by Humphry Davy will be published by the end of decade, but the meantime this paper cites their archival or printed locations. William Godwin's diary, held in the Bodleian Library, is also freely available at http://godwindiary.bodleian.ox.ac.uk/index2.html and is cited by date. Note on units: a quart is a British imperial measure of volume equivalent to 1.14 litres. Thus, seven quarts is just under eight litres.
} 
Oxide, Print Culture, $18^{\text {th }}$-century Chemistry, Pneumatic Medicine, Romantic Poetry, Lyrical Ballads, The Annual Anthology, Science and Culture.

\section{Introduction}

It is very well known that after a five-day journey from Penzance the nineteen-year old Humphry Davy (1778-1829) arrived in Clifton, near Bristol, on 7 October 1798 to take up the role of Superintendent of the new Medical Pneumatic Institution (MPI). He would hold this position for nearly two and a half years receiving an annual salary of $£ 200 .{ }^{1}$ The aim of the $\mathrm{MPI}$, established following a protracted public fundraising campaign led by Thomas Beddoes during the previous five years, ${ }^{2}$ was to investigate whether or not the factitious airs or gases identified during the previous half century or so by savants including Joseph Black (17281799), Joseph Priestley (1733-1804) and Henry Cavendish (1731-1810), possessed any therapeutic properties, especially in the cure or mitigation of consumption.

As every commentator on Davy has noted, while at the MPI he made a major discovery in pneumatic chemistry with his observations of the physiological effects of nitrous oxide ( $\mathrm{N}_{2} \mathrm{O}$, laughing gas), began his electrical researches, and became close to Southey and Coleridge. Consequences of these friendships included Davy publishing a few poems in Southey's Annual Anthology $(1799,1800)$ and in Coleridge arranging for Davy to see through the Bristol press of Nathaniel Biggs (1771-1832) and Joseph Cottle (1770-1853) the second edition of Lyrical Ballads (1800). ${ }^{3}$ Such connections with the early Romantics have always given Davy a special place both in the history of science and the history of literature. This paper seeks to understand how this special place came about in terms of what was common across all cultural activities in Bristol, including sociability and printing.

\section{Bristol and the Medical Pneumatic Institution}

\footnotetext{
${ }^{1}$ Davy to Grace Davy, 18 January 1799, RI MS HD/26/A/2.

2 Frank A.J.L. James, "'the first example ... of an extensive scheme of pure scientific medical investigation': Thomas Beddoes and the Medical Pneumatic Institution in Bristol, 1794 to 1799", Royal Society of Chemistry Historical Group Occasional Paper, 2016, no.8.

${ }^{3}$ On Davy see Harold Hartley, Humphry Davy (London: Nelson, 1966); Knight; Fullmer; Golinski, Experimental Self.
} 
Aside from brief forays to the Lake District, Cornwall and London, this essay will focus on Bristol. While the wealth of the city, the fifth largest in England, derived to a great extent from the slave trade, there were other significant sectors that contributed to its economic activity, such as glassmaking (associated particularly with the Lucas and Chance families), brasswork (the Elton family of Clevedon Court), importing drinks (Harveys of Bristol) and so on. And, of course, there were all the supporting elements required of a large city: clergy, bankers, lawyers, printers, physicians etc.

Despite being dominated by its merchant interests, Bristol nevertheless had a strong tradition of political and religious dissent. Together with its important spa at Hotwells (just to the west of the city), this radicalism contributes to understanding why Thomas Beddoes 4 chose to move there after being forced to resign his Chemical Readership at Oxford University because of his anti-government, pro-French revolution, pro-Jacobin and general democratic politics. Beddoes became subject to Home Office surveillance and harassment, appearing on a list of "Disaffected \& Seditious Persons" along with Priestley and others; he is thus one of Kenneth Johnston's Unusual Suspects. ${ }^{5}$

Beddoes first mooted the idea of using gases for therapeutic purposes just before his departure from Oxford in 1792, ${ }^{6}$ but he needed funds to pursue research and by the time of Davy's arrival in Bristol, Beddoes had obtained just over $£ 2000$ for the MPI, well short of what he wanted. ${ }^{7}$ Furthermore, it appears that some of money raised was in the form of pledges yet to be realised. The Boulton and Watt families did not make their payments until November 1799 and the gift of $£ 500$ from Tom Wedgwood (1771-1805), promised in 1797, remained outstanding in March $1800 .^{8}$ Thus during 1799 further funding for the MPI continued to be sought, for example by arranging lectures, the income from which would go

\footnotetext{
${ }^{4}$ On Beddoes see Stansfield; Porter; Levere, Enlightenment of Thomas Beddoes.

5 TNA HO42/21, f.214-5; Kenneth Johnston, Unusual Suspects: Pitt's Reign of Alarm and the Lost Generation of the 1790s (Oxford: Oxford University Press, 2013), 96-110.

${ }^{6}$ Beddoes to Davies Giddy, 2 March 1795, CRO MS DG/42/35.

7 For the details see James, "the first example".

${ }^{8}$ Beddoes to James Watt sr, 13 February 1799, LoB MS 3219/4/41/3. A note from mid-November 1799 listed payment, totalling $£ 35$ 15s, from the Boulton and Watt families, LoB MS 3219/4/41/6. This was acknowledged in Beddoes to Gregory Watt, 21 November 1799, LoB MS 3219/6/2/B/74. For the delay with Tom Wedgwood's gift, see Beddoes to Josiah Wedgwood, 20 March 1800, WM MS E1-569.
} 
to the MPI. ${ }^{9}$ The failure to reach the required amount was ascribed at the time to Beddoes's politics ${ }^{10}$ and most of the money raised came from anti-government Whig aristocrats, who, while not supporting his politics, thought his medical investigations worth carrying out.

Few of Beddoes's personal papers have survived; nor have the MPI's administrative papers, such as case-notes, laboratory notebooks, accounts etc, doubtless created during its short existence, been located. With some exceptions, accounts of those who experienced the effects of inhaling nitrous oxide exist only in Beddoes's Notice of Some Observations made at the Medical Pneumatic Institution (published November 1799) or Davy's Researches, Chemical and Philosophical; Chiefly Concerning Nitrous Oxide, or Dephlogisticated Nitrous Air, and its Respiration (July 1800) - mostly in the final part. ${ }^{11}$ Other contemporary sources relating to the MPI include Davy's notebooks (though these are far from complete and refer to other notes no longer extant), ${ }^{12}$ letters to his mother and to his major Cornish patron Davies Giddy (1767-1839). More recently, to supplement these sources, critics have used, to varying extents and degrees of success, documents from the Watt, Wedgwood and some smaller archives. To avoid problems in recent scholarship that arise from reusing quotes from other secondary sources out of context, this paper employs multiple archives with a micro-chronological emphasis, with the aim of better understanding what happened in and around the MPI during Davy's time there. As I have argued elsewhere, the MPI became the model of laboratory practice that Davy brought with him to the Royal Institution in London following his appointment there in the spring of 1801. ${ }^{13}$ The MPI thus possesses major historical significance in its own right, something that is not always recognised since the historiographical tendency has been to see it only as part of Beddoes's activities or as a place where Davy spent two and a half years in his inexorable progress from provincial obscurity to metropolitan fame.

\footnotetext{
${ }^{9}$ The Bristol Gazette, 28 March 1799, 3c and 3d.

${ }^{10}$ For example, Anne Watt to Gregory Watt, 30 March 1795, LoB MS 3219/7/1/22.

${ }^{11}$ Davy, Researches, Chemical and Philosophical, 497-541.

12 Davy's notebooks used in this paper are RI MS HD/13/H, 20/A, 20/B, 20/C, 22/B. In a number of the notebooks, Davy started at both ends, so pagination is occasionally reversed.

${ }^{13}$ Frank A.J.L. James, "The Subversive Humphry Davy," in Compound Histories: Materials, Governance and Production, 1760-1840, ed. Lissa Roberts and Simon Werrett (Leiden: Brill, 2017), 269-88.
} 
In this paper, I will take seriously and on their own terms, almost on a month by month basis, the interests and mutual interactions of Davy, Southey, Coleridge, Beddoes and their circle while they were in Bristol, centring on the MPI, in the prevailing culture and the state-repressed Jacobin political ideology in which they operated. Thus, I hope to avoid the other pitfall that tends to trap those scholars who telescope their Bristol period into a single timeframe. As Johnston has reminded us, throughout the 1790 s things changed so rapidly that it cannot be taken for granted that what pertained in October 1798 , say, did so even a few months later. ${ }^{14}$ As we shall see, relationships that were formed in Bristol during the two and a half years Davy lived there changed over time: sometimes they were very strong, sometimes they came under immense tension. They were never static and their development contributed significantly to the period's cultural and scientific production, including Lyrical Ballads. But these were exceptions. One striking aspect of the men and women who grouped, albeit with varying degrees of closeness, around Beddoes in Bristol was their sheer creativity, doubtless aided by their sociability, in developing ideas for their futures, for books, for poems, for therapies and so on, most of which never came to fruition. The early pantisocratic scheme of Southey and Coleridge is well known, but, as we will see, this was merely one example in a whole string of ideas that never came to anything.

\section{Davy in Bristol}

On his arrival in Clifton, Davy found that Beddoes had just moved into a large house in Rodney Place. Davy told his mother that 'situated on the top of a hill commanding a view of Bristol \& its neighbourhood", it possessed "above all" "an excellent laboratory." Sharing this house were Beddoes's wife, Anna Beddoes (1773-1824). Only five years older than Davy, she was one of the many daughters of the Irish landowner and educational writer Richard Edgeworth (1744-1817). She showed Davy around Clifton and they soon became "very great Friends". ${ }^{15}$

It was not only members of Beddoes's household who Davy came quickly to know. Beddoes, who had lived in Clifton for more than five years, had formed a large circle of

\footnotetext{
${ }^{14}$ Johnston, Unusual Suspects, 324.

${ }^{15}$ All quotations in Davy to Grace Davy, 11 October 1798, RI MS HD/26/A/1.
} 
acquaintances in Bristol and the surrounding area with whom Davy rapidly became involved. Some became very well-known figures such as the physician and (later) lexicographer Peter Roget (1779-1869), the publisher Joseph Cottle, the radical lawyer James Losh (1763-1833) and the tanner Thomas Poole (1766-1837). Losh saw much of Beddoes during 1798, partially as a patient, ${ }^{16}$ when he lived in Bath and later in nearby Shirehampton. There Wordsworth stayed with him during June that year, before going with Coleridge to the German-speaking lands. Others whom Davy knew are more obscure though no less significant for his life and career at this point. These included the medics John King (1766-1846) and Robert Kinglake (1765-1842), and scions of three Bristol wine merchant families, William Coates (b.1757), William Clayfield (1772-1837) and (later) Charles Danvers (c. 1764-1814). ${ }^{17}$

Davy quickly impressed everyone whom he met. During the month of his arrival, Beddoes told James Watt jr (1769-1848), "I do not recollect to have conversed with a person of so great talents for experimental investigations". ${ }^{18}$ Publicly, in The Monthly Magazine, Beddoes described Davy as "A young man, endowed with talents for experimental researches at least equal to any person I have ever known." 19 Four days after his arrival, Davy wrote to his mother that Beddoes had "given up to me the whole of the business of the Pneumatic Hospital".

Beddoes entrusted Davy with the task of spending the money which had taken so long to raise and arranged for him to visit some of the MPI's major subscribers, including the MP James Hare (1747-1804), who had queried Bristol as the best location for the MPI. ${ }^{20}$ Davy thus became involved with the business of acquiring 6 Dowry Square, an early eighteenth-century building, in which to house the MPI, ${ }^{21}$ though it is not clear whether

\footnotetext{
16 James Losh noted paying Beddoes six guineas in "Accounts", Diary, 20 October 1798, CCL MS.

${ }^{17}$ Davy, before his move to Bristol, was already acquainted with Clayfield, since he referred to him as "our friend" in Davy to Davies Giddy, 12 November 1798 in Paris, vol. 1, 64-6. According to Giddy, Diary, 1 May 1789, CRO MS DG/14, Clayfield dined with him then.

${ }^{18}$ Beddoes to James Watt jr, October 1798, LoB MS 3219/6/2/B/72.

${ }^{19}$ Monthly Magazine 6 (1798): 238.

${ }^{20}$ Davy to Grace Davy, 11 October 1798, RI MS HD/26/A/1. On Hare's role see James, "the first example", 16, 28-31.

${ }^{21}$ Davy to Davies Giddy, 12 November 1798, in Paris, vol. 1, 64-6.
} 
Beddoes had already commenced negotiations for this. ${ }^{22}$ In early January Davy visited Birmingham to meet some of the Midland industrialists who were contributing financially to the MPI. He renewed his acquaintance with Gregory Watt (1777-1804), whom he had met the previous winter in Penzance and they spent time discussing their mineral collections. ${ }^{23}$ Davy met Gregory's father, James Watt sr, and his business partner, Matthew Boulton (1728-1809), as well as their friend the industrial chemist James Keir (1735-1820).

In addition to providing financial support for the MPI, Watt sr had constructed the gas apparatus that would be at its core. This he described in the second part of Considerations on the Medicinal Use of Factitious Airs, and on the manner of obtaining them in large quantities (1794) which eventually became a five-part publication that went through a number of editions, appearing under both his and Beddoes's name. ${ }^{24}$ From Watt's initial metal apparatus, Clayfield developed a glass gasholder, described in the third part of Considerations, which Davy later found useful for quantifying the amount of gas inhaled. ${ }^{25}$

During his first few months in Clifton, Davy's position at the MPI did not require his full attention and so used the time for other activities, some of which partially subverted the original intentions behind the MPI, ${ }^{26}$ though most related to Beddoes's concerns in one way or another. For example, Davy expanded his medical learning by seeing patients in the Bristol Infirmary and also the majority of Beddoes's private patients; indeed, Davy claimed that this provided better opportunities than studying medicine in Edinburgh or London. ${ }^{27}$ Beddoes also gave Davy the task of overseeing the "printing in Bristol [of] the first volume of the "West Country Collection"'". ${ }^{28}$ Entitled Contributions to physical and medical knowledge, principally from the West of England, this collection of essays was advertised by Beddoes at the end of August 1798 as a way of raising further funding for the MPI, asserting that

\footnotetext{
22 cf Jay, p.163.

${ }^{23}$ Gregory Watt to Davy, 28 January 1799, RI MS HD/26/G/2.

${ }^{24}$ All the parts were published by Joseph Johnson in London, but printed by Bulgin and Rosser in Bristol.

${ }^{25}$ William Clayfield, "Description of a Mercurial Apparatus, Suggested by an inspection of Mr. Watt's Machine for producing and containing Factitious Airs" in Thomas Beddoes and James Watt, Considerations on the Medicinal Use of Factitious Airs, part 3, London: Johnson, printed Bristol, by Bulgin and Rosser, 1795, pp.103-5. There is a similar account by Clayfield in Davy, Researches, pp.573-6. See D. Zuck, "Humphry Davy, nitrous oxide, lung volumes and elective affinity", The History of Anaesthesia Society Proceedings, 1999, 25: 19-30.

${ }^{26}$ James, "The Subversive Humphry Davy".

${ }^{27}$ Davy to Henry Penneck, 26 January 1799, APS MS B.D315.1.

${ }^{28}$ Davy to Davies Giddy, 12 November 1798, Paris, vol. 1, 64-6.
} 
sufficient material for the first two volumes had been promised. ${ }^{29}$ By the time Davy saw the first (and only, an example of a project that failed to continue) volume through the press, an early introduction to the technicalities of book production which would stand him in good stead for the future, more than a third of it comprised two very long highly speculative papers by him. These essays Davy drafted mostly while still in Cornwall and the manuscript versions contributed to bringing him to Beddoes's attention. ${ }^{30}$ Beddoes delayed publishing Contributions, since even in early March he still expected a couple of further papers to complete the volume. ${ }^{31}$ So Davy, in a youthful rush for publication, had a few separate copies of his own papers printed off, distributing them by mid-February. ${ }^{32}$

\section{Davy and Southey}

By early 1799 Dowry Square had been acquired and Davy became busy "erecting a fine Laboratory in the Pneumatic Hospital \& I hope we shall begin our expts in a month". ${ }^{33}$ In mid-February Beddoes told Watt sr that it would soon be ready for patients. ${ }^{34}$ Unsurprisingly, delays occurred and towards the end of February, Davy told Giddy that the laboratory would be ready in early March. ${ }^{35}$ It would appear that around this time Southey first met Davy. ${ }^{36}$ Southey had attended some of Beddoes's lectures in the Spring of 1798, ${ }^{37}$ but thought him a poor versifier. ${ }^{38}$ During February 1799 Southey saw Beddoes "frequently"

\footnotetext{
${ }^{29}$ See the printed advertisement, dated 29 August 1798, in CRO MS DG/42/16.

${ }^{30}$ Davy, "An Essay on Heat, Light, and the Combinations of Light," Beddoes, Contributions, 5-147 and "An Essay On the Generation of Phosoxygen (Oxygen Gas) And on the Causes of the Colors of Organic Beings", ibid., 151205.

${ }^{31}$ Beddoes to Davies Giddy, 5 March 1799, CRO MS DG/42/12.

32 Davy to Henry Penneck, 26 January 1799, APS MS B.D315.1. Davy sent a copy of his papers to Giddy; Davy to Davies Giddy, 22 February 1799, Paris, vol. 1, 76-9 and Davies Giddy to Thomasina Dennis, 28 February 1799, CRO MS DG/87/1/25.

33 Davy to Grace Davy, 18 January 1799, RI MS HD/26/A/2. See also Davy to Henry Penneck, 26 January 1799, APS MS B.D315.1.

${ }^{34}$ Beddoes to James Watt sr, 13 February 1799, LoB MS 3219/4/41/3.

35 Davy to Davies Giddy, 22 February 1799, Paris, vol. 1, 76-9.

${ }^{36}$ Hardly the swift connection referred to in Jay, 162.

37 Southey to John May, 1 May 1798, CLRS.

${ }^{38}$ Southey to Charles Wynn, 26 January 1797, CLRS. cf Norman A. Bergman, The Genesis of Surgical Anaesthesia (Park Ridge: Wood Library, 1998), 252.
} 
for medical advice. ${ }^{39}$ That month Southey first referred to Davy in his letters, noting "a very extraordinary young man lately settled here" and adding that he had been "labouring at his Essays on Light \&c, but he is going to show me his poems, of which I hear much from tolerable judges". ${ }^{40}$ That Davy had not yet shown Southey his poems does suggest that they had only met quite recently. After meeting Davy, Southey began taking a strong interest in the MPI, telling a friend in mid-March that it would open the next day, though he expressed some concern: "if the first trials should prove unsuccesful [sic] ... an outcry will be raisd against it. they will also find a difficulty in getting patients. even in hopeless disorders people are not fond of having experiments tried upon them". ${ }^{41}$

The MPI did eventually open, advertised in The Bristol Gazette on 21 March, which noted that it would be attended, presumably daily, by Beddoes and Davy between 11am and $1 \mathrm{pm} .{ }^{42}$ Later Kinglake and Roget would be listed as physicians to the MPI, ${ }^{43}$ although the latter's connection would be brief. Soon afterwards, Davy drafted a "Prospectus" for the MPI (though it is not clear if this was ever printed) writing that "upwards of forty are become outpatients [at the MPI] within this fortnight \& we could immediately fill the house with in patients". ${ }^{44}$ Davy was right: as Beddoes related in April, the fear

that people wd not venture to the pneumatic Instn out of dread of having experiments made upon them is pretty well over - We have now about 70 patients - all outpatients - for only part of our furniture is yet put in - All these patients are decent people - small tradespeople \& upper servants - \& they like better to come to us than go to the dispensary or a hospital whither indeed they wd not go at all - We reject none - but give such prescriptions as we think suited to their cases, where they do not suit our

\footnotetext{
${ }^{39}$ Southey to Grosvenor Bedford, 10 February 1799, CLRS.

40 Southey to William Taylor, 24 February 1799, CLRS.

${ }^{41}$ Southey to William Taylor, 12 March 1799, CLRS.

42 The Bristol Gazette, 21 March 1799, 3c. A few days later Southey noted that the MPI had "just opened". Southey to Charles Wynn, 30 March 1799, CLRS.

${ }^{43}$ Matthew's Complete Bristol Directory for the years 1799 \& 1800 (Bristol: Matthews, 1799/1800).

${ }^{44}$ Davy, "Prospectus of the design of the Institution," [mid-April 1799], RI MS HD/20/B, 11-16, quotation on 14. Beddoes in a letter dated 24 March 1799 wrote that he would "immediately circulate a prospectus". Beddoes, "Letter ... respecting the Discovery of Sulphate of Strontian", Nicholson's Journal 3 (1799): 41-2, (42), but no evidence of publication has been found.
} 
peculiarities of practice - $\&$ I think we have performed cures enough to establish a reputation. ${ }^{45}$

As Beddoes's reference to prescriptions suited to their cases indicates, it was not necessarily gas therapy these patients received. At the beginning of March, Beddoes began using digitalis, derived from foxgloves, as a treatment for consumption, an idea suggested to him independently by a couple of correspondents. ${ }^{46}$ Towards the end of April Beddoes told the potter Josiah Wedgwood (1769-1843), that “Our pneumatic Instn goes on prosperously. We have completely established the power of digitalis in consumption" and cited its application to Anna Beddoes who, though she disliked it, had by its use been "snatched out of the doors of death" ${ }^{47}$ Beddoes seems to have perceived no incongruity in juxtaposing the MPI and digitalis suggesting, as I have discussed elsewhere, that after five years of fund raising for the MPI, Beddoes had lost focus on investigating gas-based therapies. ${ }^{48}$ Southey did, however, see the discrepancy, writing in mid-April, "Beddoes \& his young assistant are doing wonders at the Pneumatic Institution - but not by the gasses. what they wanted for consumptions seems to be found in the fox glove tincture". ${ }^{49}$

\section{Annual Anthology, volume 1}

By this time Davy had shown Southey some poems he had written (or least drafted) when aged sixteen and seventeen. Southey, impressed with these "early productions of genius", invited Davy to contribute a few to what he then termed his "Almanach". ${ }^{50}$ This would be published later in the year as the first volume of his Annual Anthology. As with so many of the books produced during these years by those connected with Beddoes and the MPI, though not Considerations, it would be printed in Bristol by the partnership of Nathaniel Biggs and Joseph Cottle but published in London, usually by Longman. The partnership, in

\footnotetext{
45 Beddoes to James Watt sr, early April 1799, LoB MS 3219/4/41/5.

${ }^{46}$ Beddoes to Davies Giddy, 5 March 1799, CRO MS DG/42/12. See J.K. Aronson, An Account of the Foxglove and its Medical Uses 1785-1985 (Oxford: Oxford University Press, 1985), 310-12.

${ }^{47}$ Beddoes to Josiah Wedgwood, 23 April 1799, WM MS E1-564. See also Beddoes to James Watt sr, 29 May 1799, LoB MS 3219/4/41/4.

48 James, "the first example", 31-3.

${ }^{49}$ Southey to William Taylor, 15 April 1799, CLRS.

50 Ibid.
} 
which Cottle seems to have been a sleeping partner, lasted from 1798 to 1803 and its formation appears related to Cottle's impending bankruptcy due to the failure of the Kennet and Avon Canal. ${ }^{51}$ Curiously most of the poetry books produced by the partnership were imprinted "Biggs and Co" while other books were inscribed "Biggs and Cottle". ${ }^{52}$ At the very least this seems to suggest a deliberate downplaying of Cottle's role in publishing the work of those he knew well such as Southey, Coleridge and Wordsworth.

The idea for an Almanach, modelled on Continental practice, came from Southey's friend William Taylor (1765-1836) who suggested to him in September 1798 that it would be useful to publish "an annual Anthology of minor poems - too unimportant to subsist apart, and too neat to be sacrificed with the ephemeral victims of oblivion". ${ }^{53}$ With many of his own poems unpublished, by the end of the year Southey had commenced working on what he hoped would be the first volume in a series, persuading some of his friends to contribute also. ${ }^{54}$ Davy, now added to the list, provided five poems, four of which he dated to 1795 or 1796. Versions of four of these are contained in one of his notebooks where he not only prepared them for publication, but in an example of not developing an idea, he also seems to have contemplated producing his own volume of verse. ${ }^{55}$ Although each of Davy's poems was printed on different gatherings of The Annual Anthology, there is no further evidence to suggest when between April and August Davy submitted his final texts to Southey.

\section{Nitrous Oxide}

\footnotetext{
51 Paul Cheshire, "Coleridge's Poems 1803: The Fall of Cottle and the Rise of Longman," The Coleridge Bulletin 47 (2016): 21-40.

52 An exception is the very rare [William Wordsworth and Samuel Taylor Coleridge], Lyrical Ballads with a few other Poems (London: Longman, printed Bristol, by Biggs and Cottle, 1798).

53 William Taylor to Southey, 26 September 1798, in J.W. Robberds, A Memoir of the Life and Writings of the Late William Taylor of Norwich, 2 vols (London: Murray, 1843), vol. 1, 228.

54 Southey to William Taylor, 30 December 1798, CLRS.

55 In RI MS HD/13/H, p.43 Davy listed the poems. The poems published by him in Annual Anthology. Volume I, (London, Longman, printed Bristol by Biggs and Co., 1799) are (followed in parentheses by pagination, gathering letter, date and MS pagination in RI MS HD/13/H): "The Sons of Genius" (93-9, F, 1795, 76-64); "The Song of Pleasure" (120-5, H, 1796, 48-52); “Ode to St. Michael's Mount" (172-6, L, 1796, 46); “The Tempest" (179-80, M, 1796, 59); "Extract from an unfinished poem upon Mount's-Bay" (281-6, S, nd, no MS). The first six stanzas of the ode to St Michael's Mount are copied out neatly (not by Davy) in RI MS HD 20/B, 236-3, with the comment in Davy's hand after all but the first "very pretty". For further discussion see Wahida Amin, The Poetry and Science of Humphry Davy, University of Salford PhD thesis, 2013, 50-1.
} 
During these early exchanges of poetry, in mid-April Davy told Southey ${ }^{56}$ about what were the initial stages of his uncovering the remarkable physiological properties of dephlogisticated nitrous air (as Priestley, its discoverer, named it), or nitrous phosoxyd (as Davy initially termed it) or, following Lavoisierian nomenclature, gaseous oxide of azote or nitrous oxide. The consequences of this discovery, which strongly engaged Southey's interest, would dominate Davy's work in the ensuing months, culminating in the publication of his Researches. Davy there recollected that shortly after commencing his chemical studies, whilst still in Cornwall in March 1798, he investigated the claim that nitrous oxide caused "terrible effects" when breathed or even by just coming in contact with animals. ${ }^{57}$ With the resources available in Penzance he convinced himself of the incorrectness of this view, but could go no further. That he was waiting for the opening of the MPI to resume this investigation is clear from a February 1799 letter to Giddy asserting that "We shall begin by trying the gases in their simplest mode of application, and gradually carry on the more complex processes" and then specifically referred to studying the effects of "gaseous oxide of azote" ${ }^{58}$ Davy later recollected in Researches that at the start of March, he produced the impure gas in large quantities ${ }^{59}$ and began both self-experimenting and administering it to others. That month both Southey and C. Coates ${ }^{60}$ found that inhaling the gas produced tendency to faint, giddiness and slower pulse; ${ }^{61}$ the latter observation Beddoes reported to Watt sr at some point early in April. ${ }^{62}$ During the first part of April Davy made pure nitrous oxide and this produced the first piece of surviving contemporary evidence relating to his investigation. In a letter of 11 April 1799 to Nicholson's Journal he briefly reported experiments, presumably performed in the preceding days, of the effects the gas on animals and of breathing both the gas himself both pure (twice) and mixed with oxygen. The former produced no "disagreeable effects" while the mixture produced effects that "were very

\footnotetext{
56 The first extant reference by Southey to the gas is in Southey to William Taylor, 15 April 1799, CLRS; however, his wording is ambiguous as to whether he had as yet direct experience of the gas.

57 Davy, Researches, Chemical and Philosophical, 453.

${ }^{58}$ Davy to Davies Giddy, 22 February 1799, Paris, vol. 1, 76-9.

59 Davy, Researches, Chemical and Philosophical, 454. See also RI MS HD/20/B, 110.

60 Possibly William Coates's sixteen-year old son, Charles.

${ }^{61}$ Davy, Researches, Chemical and Philosophical, 455.

62 Beddoes to James Watt sr, early April 1799, LoB MS 3219/4/41/5. This letter is mistakenly endorsed "July 1799".
} 
peculiar: should they be confirmed by future experiments, it will probably prove a valuable medicine" thus emphasising the MPI's therapeutic aims. ${ }^{63}$ As Davy recollected in his Researches, it was on 11 April that he inhaled the pure gas, making no reference to experiencing any physiological effects, only that the gas could be safely breathed. ${ }^{64}$ The minimal effect of inhaling the gas was also the impression provided by Southey a few days later. ${ }^{65}$

Davy's early accounts describing the effects of nitrous oxide are not especially detailed. They give no information as to what he thought the purity of the gas might be, nor did he note the volumes he inhaled or for how long. This would change in the experiments he conducted during the second half of April. Again, according to his Researches, on the 16th, with Kinglake present, Davy inhaled three quarts for just over thirty seconds. This produced in him a slight giddiness, a feeling similar to "the first stage of intoxication; but unattended by pleasurable sensation" and Kinglake noted a quicker pulse. ${ }^{66}$ The following day, in Beddoes's presence, Davy inhaled four quarts and the day after, 18 April, with Beddoes, James Webbe Tobin (1767-1814) ${ }^{67}$ and others present he undertook many experiments including breathing sixteen quarts in seven minutes, which made him "dance about the laboratory as a madman". ${ }^{68}$ The results of this set of experiments prompted Davy, at some point after mid-April, to send a note cautioning about inhaling gases to Nicholson's Journal adding that he would be publishing details of the hazards in due course. ${ }^{69} \mathrm{~A}$ day or two later Tobin inhaled the gas for the first of many times, later writing a report describing his experiences. This process would be repeated often by those on whom Davy tried the gas, the results of which were published in his Researches. ${ }^{70}$ But Davy also kept self-

\footnotetext{
63 Davy, "Letter ... introductory to the Experiments contained in the subsequent Article, and on other Subjects relative to the Progress of Science," Nicholson's Journal 3 (1799): 55-6 (55).

${ }^{64}$ Davy, Researches, Chemical and Philosophical,.456.

${ }^{65}$ Southey to William Taylor, 15 April 1799, CLRS.

${ }^{66}$ Davy, Researches, Chemical and Philosophical, 456-7.

${ }^{67}$ Davy, Researches, Chemical and Philosophical, 497; Beddoes, Notice, 9. Tobin, the son of George Tobin, was not a physician as asserted in Jay, 177.

${ }^{68}$ Davy to Davies Giddy, 18 ? April 1799, in Paris, vol. 1, 79-82.

69 Davy, "Respirability of the Gaseous Oxyd of Azote. Extract of a Letter," Nicholson's Journal, 3 (1799): 93.

70 James Webbe Tobin, October 1799, in Davy, Researches, Chemical and Philosophical, 497-502.
} 
experimenting and, for example, on 3 May decided to investigate the effect that the gas would have on sleeping by inhaling at $8 \mathrm{pm}$ twenty-five quarts of gas; he found no effect. ${ }^{71}$

Beddoes immediately saw the potential for major therapeutic value in the gas, writing to Josiah Wedgwood that he had "great hopes of palsy" and even thought the gas would "stimulate Tom [Wedgwood]'s torpid machine" adding that the discovery "will realise the expectations and conjectures I originally stated". ${ }^{72}$ In other words the MPI, in which the Wedgwood family had invested so much money, was fulfilling its promise especially in regards to Tom's illness - it was money well spent.

During May, Roget arrived in Bristol. A month younger than Davy, Roget graduated MD from Edinburgh University in June 1798. At Edinburgh, he became acquainted with Lovell Edgeworth (1775-1842), Anna Beddoes's half-brother. During his visit, Roget inhaled nitrous oxide and in July wrote Davy a description of his experiences which included vertigo and tingling in his hands and he did not "experience the least pleasure from any of these sensations". ${ }^{73}$ Roget may be one of the philosophers to whom Beddoes's step-mother-inlaw Frances Edgeworth (1769-1867,) also visiting Clifton that May, referred to as finding when they inhaled, "nothing but a sick stomach \& a giddy head". Although she referred to the gas as giving the "sensations of the Nectar of the Gods", she fully recognised that not everybody reacted in the same way, writing that "faith, great faith is I believe necessary to produce any effect". ${ }^{74}$

In June Davy continued experimentation both on himself and others while at the same time he "worked incessantly at the chemistry of this elastic fluid". ${ }^{75}$ Kinglake inhaled

\footnotetext{
${ }^{71}$ Davy, Researches, Chemical and Philosophical, 461-2.

72 Beddoes to Josiah Wedgwood, 23 April 1799, WM MS E1-564. See also Beddoes to Erasmus Darwin, midApril 1799, in Stock, 177.

73 Peter Roget, [July 1799], in Davy, Researches, Chemical and Philosophical, 509-12, quotation on 511. Another, similar, description of his experiences is in Roget to Jeremy Bentham, 9 January 1800, The Correspondence of Jeremy Bentham, ed. J. R. Dinwiddy, vol. 6 (Oxford: Oxford University Press, 1984), 24-6; hereafter cited as Bentham, Correspondence, vol. 6 followed by page number. Roget's account to Davy is dated on the basis of this letter.

${ }^{74}$ Frances Edgeworth to Margaret Ruxton, 26 May 1799, National Library of Ireland MS 10166/7/226. Jay, 186, Holmes, Age of Wonder, 264 and Bergman, Surgical Anaesthesia, 255 all asserted that this letter was written by Maria Edgeworth. Golinski, Science as Public Culture, 170 has referred the problem of replicating the effects of the gas, which as we will see occurred quite frequently, to the different contexts in which the experiments were conducted.

${ }^{75}$ Beddoes to James Watt jr, 27 June 1799, LoB MS 3219/6/2/B/73.
} 
and in the middle of the month wrote Davy an account of his pleasurable experiences. ${ }^{76}$ Southey also inhaled that month, though It is not entirely clear when he began, ${ }^{77}$ but on the fifth described it as a "wonder-working gas", 78 a phrase adopted by others. ${ }^{79}$ However, at this point he was more interested in Beddoes's foxglove treatment. ${ }^{80}$ As a result of Davy's experiments, Beddoes now started giving serious consideration to the possible therapeutic value of nitrous oxide. In a letter to Gregory Watt at the end of May, Giddy discussed how the gas might work medically (information that he could only have obtained from letters either from Davy or Beddoes now lost) concluding that "its uses and virtues may be beyond calculation". ${ }^{81}$ A month later Beddoes told Robinson Boulton (1770-1842), son of Matthew Boulton, that "Davy goes on very successfully making preparatory experiments for the pneumatic Instn". ${ }^{2}$ The same day he wrote to James Watt jr telling him that he and Davy had "concluded that it wd be of use in palsy \& in hopeless cases of debility" and had cautiously begun clinical trials. One involved administering the gas to a hemiplegic patient who as a consequence threw "away his crutch \& walks without support" ${ }^{83}$ All in all Beddoes believed that these results meant "the present will be the most splendid æra in medicine". ${ }^{84}$ Davy also noticed at some point that as nitrous oxide seemed "capable of destroying physical pain, it may be used during surgical operations", but he took this suggestion no further. ${ }^{85}$

\footnotetext{
${ }^{76}$ Kinglake, 14 June 1799, in Davy, Researches, Chemical and Philosophical, 503-7; Beddoes, Notice, 12.

77 Beddoes, Notice, 11; Southey, nd, in Davy, Researches, Chemical and Philosophical, 507-9.

78 Southey to Grosvenor Bedford, 5 June 1799, CLRS.

${ }^{79}$ For example, Beddoes to James Watt jr, 27 June 1799, LoB MS 3219/6/2/B/73 and Bentham to Roget, 4 September 1800, Bentham, Correspondence, vol. 6, 346-9.

80 Southey to John May, 10 June 1799, CLRS.

81 Davies Giddy to Gregory Watt, 26 May 1799, LoB MS 3219/7/5/56.

82 Beddoes to Robinson Boulton, 27 June 1799, LoB MS 3782/13/8/20.

83 Beddoes to James Watt jr, 27 June 1799, LoB MS 3219/6/2/B/73.

${ }^{84}$ Beddoes to James Watt jr, 27 June 1799, LoB MS 3219/6/2/B/73.

85 Davy, Researches, Chemical and Philosophical, 556. See also $464-5$ for similar comments. These passages have been seen inappropriately by some (e.g. F.F. Cartwright, The English Pioneers of Anæsthesia (Beddoes, Davy, and Hickman) (Bristol: Wright, 1952), 319) as the beginnings of anaesthesia, thus immediately raising the problem of why it was not implemented for more than three decades. Golinski, Science as Public Culture, 175 suggested this neglect stemmed from the association of the gas with radical politics and entertainment. For a criticism see Margaret Jacob and Michael Sauter, "Why Did Humphry Davy and Associates Not Pursue the PainAlleviating Effects of Nitrous Oxide?," Journal of the History of Medicine 57 ( 2002): 161-76, 175. See also Bergman, Surgical Anaesthesia, 278.
} 
There is little evidence suggesting that clinical trials continued during July or August, though administering the gas to individuals did, with the consequent reporting of its mindaltering effects. Davy's notebook recording his experiments in mid-July, the only one to have survived from this time, ${ }^{86}$ included an account of Southey and his wife Edith Southey (17741837) inhaling on 13 July. Southey described the experience later that day:

I have been breathing a newly discovered gas which produces the most extraordinary effects. laughter, a delightful sensation in every limb - in every part of the body - to the very teeth, \& increased strength with no after relaxation. it is a high pleasure for which language has no name, \& which can be estimated by no known feeling. I took some this morning \& still feel increased strength \& spirits. $^{87}$

Some material evidence of the augmented physical and mental sensations produced in those attuned to the gas can be seen when Davy, on 27 August, after inhaling seven quarts of nitrous oxide, wrote in his note book in inch high letters "Davy \& Newton". An indication, possibly unconscious, of his vaunting ambition. ${ }^{88}$

\section{Annual Anthology volumes 1 and 2}

Quite whether Davy's inhalations affected his fifth and final contribution to the first volume Southey's Annual Anthology, published towards the end of August is not clear. ${ }^{89}$ Entitled "Extract from an unfinished poem upon Mount's-Bay", 90 it was the only one of Davy's poems in the volume to be published under his name. Sending a copy to his mother Davy described it as "a poem on the place of my nativity" 91 and it is shot through with Cornish

\footnotetext{
${ }^{86} \mathrm{RI} \mathrm{MS}$ HD/20/B. Although Davy did date quite a few notes, some were misdated (under the influence of the gas?). He later tried to correct them and, occasionally, it is hard to tell whether he did so accurately.

${ }^{87}$ RI MS HD/20/B, 208 and Southey to Charles Wynn, 13 July 1799. For similar comments see Southey to Thomas Southey 12 July 1799 and Southey to William Taylor, 1 September 1799, all CLRS.

${ }^{88} \mathrm{RI} \mathrm{MS} H \mathrm{HD} / 20 / \mathrm{B}, 182$. A few months later on 27 April 1800, also under the influence of nitrous oxide, Davy wrote that he "was born to benefit the world by my great talents \&c.", RI MS HD/20/B, 153.

${ }^{89}$ Southey to Cottle, 25 August 1799, CLRS, acknowledged receipt. Holmes, Age of Wonder, 269, wrote that the volume was published in December.

${ }^{90}$ See note 55 .

${ }^{91}$ Davy to Grace Davy, 1 September 1799, SM MS 333/1. No example of an off-print of Davy's poem has been found.
} 
legends, history and geology. Southey, writing to Davy from Exeter, compared the poem with the work of John Milton (1608-1674). With such extravagant praise, it is little wonder that he wished for a longer poem..$^{92}$ On the other hand Southey writing to Taylor criticised "Sons of Genius" describing it as "tedious \& feeble", though he attributed this to Davy being only eighteen when he wrote it. ${ }^{93}$ Writing privately at the start of 1800 John Gifford (17581818), who edited the ultra-conservative, government supporting, Anti-Jacobin Review, described the Anthology as a "miserable collection of poems" but added "The only good poem is that addressed to St. Michael's Mount, by a young man of Penzance, an assistant to Dr. Beddoes in chemical experiments. He is without doubt extremely clever, and has given Beddoes the most ample satisfaction". ${ }^{94}$ Such a comment suggests that somehow Gifford was being kept well informed of developments in Bristol. Whether Gifford's opinion explains the omission of specific reference to Davy from the short hostile note on the Anthology published in the June issue of the Review, is not clear. The reviewer criticised the contributors for being "tinctured with Jacobinism" and held "their politics and their poetry, in equal contempt". 95

The phrasing of Southey's comments on "Mount's Bay" suggests that he had not read it before publication and thus provides evidence of Cottle's role in editing The Annual Anthology. Southey was happy with the inclusion of "Mount's Bay", printed on the penultimate gathering. But he was very angry with Cottle for printing, on the same sheet, a short anonymous poem by Beddoes, "Domiciliary Verses December 1795"96 which, in Southey's view, lampooned Wordsworth, and which he had already told Cottle not to publish. However, when Beddoes threatened to withdraw an already printed poem of his ${ }^{97}$ Cottle capitulated. ${ }^{98}$ At this point relations between Coleridge and Southey were strained and the latter did not wish to offend either him or his friend Wordsworth who, however,

\footnotetext{
92 Southey to Davy, 4 September 1799, CLRS.

93 Southey to William Taylor, 27 October 1799, CLRS.

94 John Gifford to Richard Polwhele, 9 January 1800, in Richard Polwhele, Traditions and Recollections; Domestic Clerical, and Literary, 2 vols (London: Nichols, 1826), vol. 2, 525-6.

${ }^{95}$ Anti-Jacobin Review, 6 (1800), 215-16 (216).

${ }^{96}$ Annual Anthology, 1 (1799): 287-8.

97 T[homas] B[eddoes], “On some Modern Improvements In a celebrated Spot in Gloucestershire," Annual Anthology, 1 (1799): 248 [sheet Q].

98 Southey to Davy, 4 September 1799, CLRS.
} 
was quite relaxed about the matter. ${ }^{99}$ In letters to both Cottle and Davy, Southey accused Beddoes of arrogance, impertinence and indelicacy and instructed Cottle never to commission a poem from him again. ${ }^{100}$

However, none of this prevented Southey from continuing to be Beddoes's patient ${ }^{101}$ or from involving Cottle in the second volume of The Annual Anthology which he hoped to send to the press by December, ${ }^{102}$ although poems were still being submitted in late February. ${ }^{103}$ Southey was back in Bristol in December to be treated for what was clearly a serious medical condition. ${ }^{104}$ Having seen one physician, on the ninth Southey told a friend that he would put himself "under Beddoes, in whom I have complete faith" ${ }^{105}$ Five days later, writing to the same friend, he said he had not consulted Beddoes. Instead he had seen Davy whom he regarded as a "superior man infinitely"106 over his usual apothecary whom he had also consulted.

\section{Testing and Publishing Nitrous Oxide}

During September Davy continued self-experimentation on himself and others including his old friend James Thomson (1779-1850) and the surgeon Stephen Hammick (1777-1867), both of whom derived pleasure from their experiences. ${ }^{107}$ Also in Clifton at this time were two of Joseph Priestley's children - Sarah (Sally) Finch (1763-1803) and Joseph Priestley jr (1768-1833). Sarah was suffering severely from consumption but believed she was

\footnotetext{
99 Wordsworth to Cottle, 2 September 1799, in James A. Butler, "Wordsworth, Cottle, and The Lyrical Ballads: Five Letters, 1797-1800," The Journal of English and Germanic Philology, 75 (1976): 139-53, 150-1.

100 Southey to Cottle, 25 August 1799; Southey to Davy, 4 September 1799, both CLRS. On this episode, see Duncan Wu, "Lyrical Ballads (1798): The Beddoes Copy," The Library 5 (1993): 332-5.

${ }^{101}$ Southey to Grosvenor Bedford, 10-13 November 1799; Southey to Charles Wynn, 18 November 1799, both CLRS.

102 Southey to Cottle, 22 September 1799, CLRS.

${ }^{103}$ Coleridge to Southey, 28 February 1800, CLRS.

${ }^{104}$ Southey to Coleridge, 5 December 1799, CLRS.

105 Southey to Charles Wynn, 9 December 1799, CLRS.

106 Southey to Charles Wynn, 14 December 1799, CLRS.

${ }^{107}$ RI MS HD/20/A, 16 and 33. Stephen Hammick, 15 September 1799 and James Thomson, 21 September 1799, Davy, Researches, Chemical and Philosophical, 522-3 and 512-16 respectively. Beddoes, Notice, 10-11 and 10 respectively.
} 
recovering; Beddoes thought her case "almost hopeless"108 and she died aged forty in 1803. Joseph jr experimented with Davy at the start of October, but wrote in his account that he did not enjoy inhaling nitrous oxide. ${ }^{109}$ At the start of September Watt sr and his wife took the opportunity to witness Davy's experiments when they visited Clifton for a few days as part of a tour of Wales and south-west England looking for a suitable country estate. At the MPI Davy showed them the administration of gas to a couple of patients suffering from palsy which Anne Watt (c.1744-1832) reported gave them much benefit. ${ }^{110}$ Watt sr's inhalation of nitrous oxide benefited his leg, though his wife became hysterical. ${ }^{111}$ Davy discussed with Watt sr the possibility of constructing a breathing chamber for the gases, and eventually he suggested something the size of a sedan chair. ${ }^{112}$ Following their return to Birmingham, James Watt sr and Gregory sought to make the gas but, as with Roget's experience, were not able to replicate the same pleasurable physiological effects, as noted earlier by Frances Edgeworth. Gregory thus asked Davy “by what process you generate sublime sensations and be the ladder by which we may ascend to the Heaven of Heavens". ${ }^{113}$ He later achieved the object of his desire, but the effect was not as great as on other people. ${ }^{114}$

Davy recognized that these kinds of enquiries would best be addressed by publishing an account of the results of the enormous amount of work undertaken at the MPI. In April, Davy stated publicly that he was writing a paper for inclusion in a second volume of the

\footnotetext{
108 Anne Watt to Gregory Watt, 6 September 1799, LoB MS 3219/7/1/52.

${ }^{109}$ RI MS HD/20/A, 53; Davy, Researches, Chemical and Philosophical, 535.

${ }^{110}$ Anne Watt to Gregory Watt, 6 September 1799, LoB MS 3219/7/1/52. Perhaps these were the same paralytic patients that Davy told Southey the following month that he had cured (see Southey to Davy, 27 October 1799, CLRS).

${ }^{111}$ Gregory Watt to James Watt sr, 9 September 1799, LoB MS 3219/7/49/22. This was a reply to a letter, not found, but which would have contained these descriptions. For a later account of the Watts's experiences see James Watt sr to Joseph Black, 9 November 1799, Black, vol. 2, 826. See also Beddoes, Notice, 20 for Watt sr, while Anne Watt is probably the person referred to as "Mrs. W" in ibid., 18.

112 James Watt sr and Gregory Watt to Davy, 13 November 1799, RI MS HD/26/G/3. For a plausible reconstruction of this see Seth C. Rasmussen, "It's a Gas! Sir Humphry Davy and His Pneumatic Investigations," in Characters in Chemistry: A Celebration of the Humanity of Chemistry, ed. Gary D. Patterson and Seth C. Rasmussen (Washington: American Chemical Society, 2013), 101-28 (113-14).

113 James Watt sr and Gregory Watt to Davy, 13 November 1799, RI MS HD/26/G/3.

114 Davy, Researches, Chemical and Philosophical s, 536. See also Gregory Watt to James Watt sr, 19 October 1800, LoB MS 3219/7/50/7.
} 
West Country contributions planned by Beddoes but in the end never published. ${ }^{115}$ Wherever the blame lay, the lack of a proper account of Davy's investigations must have seemed unfortunate. During October 1799 Beddoes wrote his Notice of Some Observations made at the Medical Pneumatic Institution, which was published during early November. ${ }^{116}$ This short (forty-five page) text outlined the physiological and therapeutic effects of inhaling nitrous oxide by providing brief case histories of nearly thirty individuals. Very quickly Thomas Hope (1766-1844), who knew Beddoes well from their time as students at Edinburgh University before taking over as Professor of Chemistry there, added the topic to his lectures, though he warned that Beddoes's account was "perhaps exaggerated". ${ }^{117}$ In 1801 Davy expressed delight that Edinburgh professors had "taken up the subject with great ardour". 118

Beddoes's Notice of November 1799 contains the only surviving accounts of the nitrous oxide experiences of some figures, such as the radical author Anna Barbauld (17431825), her husband the Unitarian Rochemont Barbauld (1749-1808), and Anna Beddoes. ${ }^{119}$ As usual with Beddoes's publications, he added text to them as the sheets went through the press. Right at the end of the Notice Beddoes described the pleasurable effect that nitrous oxide had on Coleridge. Beddoes had known Coleridge since the mid-1790s when they organised protests against various repressive measures introduced by the government. Davy just missed meeting him when he arrived in Bristol in October 1798 due to Coleridge's recent departure for the German-speaking lands. As Coleridge was in Nether Stowey on 15 October $1799^{120}$ and departed with Cottle from Bristol for the north on the $22 \mathrm{nd},{ }^{121}$ we can be confident that in between those dates Coleridge, Beddoes and Davy experimented with

\footnotetext{
115 Davy, “Respirability of the Gaseous Oxyd of Azote. Extract of a Letter," Nicholson's Journal 3 (1799): 93.

116 It was advertised in The Morning Chronicle, 11 November 1799, 2a. However, Black had received a copy by the $6^{\text {th }}$ (see Joseph Black to James Watt sr, 6 November 1799, in Black, vol. 2, 824). "Medical Pneumatic Institution", Philosophical Magazine 5 (1799): 301-5, published in December, quoted extensively from Beddoes's text.

117 John Lee's notes of Hope's lectures, 17 January 1800, Edinburgh University Library MS Dc.8.154, 16.

118 Davy to John Tonkin, 12 January 1801, in John Davy, Memoirs of the Life of Sir Humphry Davy, Bart., 2 vols, (London: Longman, 1836), vol. 1, 107-9.

119 Beddoes, Notice, 9, 9 and 10 respectively.

${ }^{120}$ Coleridge to Southey, 15 October 1799, Coleridge Letters, vol. 1, 538-42.

${ }^{121}$ George Hartley Buchanan Coleridge, "Samuel Taylor Coleridge Discovers the Lake Country," in Wordsworth and Coleridge: Studies in Honor of George McLean Harper, ed. Earl Leslie Griggs (Princeton: Princeton University Press, 1939), 135-65. Jay, 191, is incorrect in his dating.
} 
the gas. ${ }^{122}$ Davy at this point seems to have been working twelve to fourteen hour days "in laborious experiments" where he "generally breathed an atmosphere loaded either with the fumes of the evaporable acids or Ammonia". ${ }^{123}$ This, together with his extended and sustained self-experimentation with nitrous oxide damaged his health, as Beddoes made clear in a letter to Robinson Boulton, though he also considered the possibility that Davy might be suffering from consumption. ${ }^{124}$ Thus, shortly after Coleridge and Cottle departed Davy returned to Cornwall where he spent most of November $1799 .{ }^{125}$ The visit restored his health and gave him "an opportunity of comparing the effects of the gas with those of moderate doses of wine; they appeared analogous as to the pleasure"..$^{126}$

\section{Annual Anthology, volume 2}

Davy's trip to Penzance also prompted a poem entitled: "Lines: Descriptive of feelings produced by a visit to the place where the first nineteen years of my life were spent, on a stormy day, after an absence of thirteen months". As Alice Jenkins has pointed out, both Davy's title and poem make more than a passing nod to Wordsworth's "Lines written a few miles about Tintern Abbey, on revisiting the Banks of the Wye during a tour, July 13, 1798" published in the first edition of Lyrical Ballads. ${ }^{127}$ Davy's poem was published in the second volume of The Annual Anthology, advertised in May 1800. ${ }^{128}$ While Davy's "Lines" were mostly recollective and meditative, he also reflected on his time in Bristol and those whom he had met, acknowledging and illustrating the importance to him of the sociability he found in the city and for his work both in poetry and science:

For I have tasted of that sacred stream

\footnotetext{
122 Beddoes, Notice, 40; Davy, Researches, Chemical and Philosophical, 516-17. Holmes, Age of Wonder, 267, asserted that Davy and Coleridge first met on 22 October 1799, the day of the latter's departure for the north. ${ }^{123}$ RI MS HD/20/B, 121.

${ }^{124}$ Beddoes to Robinson Boulton, 22 November 1799, LoB MS 3782/13/8/21; Southey to Charles Wynn, 9 December 1799, CLRS. See also the much later (4 January 1831) recollection by Davy's sister, Catherine, of his state of health then, RI MS HD/26/D/75.

125 Not two weeks as stated in Jay, 189.

${ }^{126}$ RI MS HD/20/B, 121.

${ }^{127}$ Alice Jenkins, "Humphry Davy: Poetry, Science and the Love of Light," in 1798: The Year of the Lyrical Ballads, ed. Richard Cronin (Houndmills: Macmillan, 1998), 133-50 (144).

128 The Star, 22 May 1800, 1 b.
} 


$$
\begin{aligned}
& \text { Of Science, whose delicious waters flow } \\
& \text { From Nature's bosom. I have felt the warm, } \\
& \text { The gentle influence of congenial souls } \\
& \text { Whose kindred hopes have cheered me. }{ }^{129}
\end{aligned}
$$

As the volume went through the press, Davy informed Tobin that his "favorite poeticojacobinical Anthology is nearly printed". ${ }^{130}$ Davy's neologism, coined before the AntiJacobin Review commented on the first volume of Annual Anthology, suggests both the influence of Coleridge's use of language on him and also, at least to Tobin, an implication of pro-Jacobinism. As so often with Davy it is difficult to form any kind of judgement about whether this was indeed the political opinion he held at this time, or whether he just wrote something he knew would be well received by the recipient.

\section{Therapeutics}

Evidently, while in Penzance Davy suffered withdrawal symptoms, since on his return to Bristol after thirty-three days without the gas, he immediately inhaled nine quarts of nitrous oxide. ${ }^{131}$ Despite referring to the effects of the gas as "the most beneficial discovery ever made", 132 during Davy's absence Beddoes had developed a novel therapy of putting patients in with cows. By that time there were five lady in-patients (one of whom was probably Sally Finch $^{133}$ ) inhaling the breath of an Alderney cow, ${ }^{134}$ and Watt sr reported the beneficial effects on their consumption. ${ }^{135}$ Shortly thereafter Beddoes asked Giddy and Watt jr if they would invest $£ 50$ and $£ 200$ respectively to support further work on what could be termed Alderney Cow Therapy. ${ }^{136}$ Giddy's response has not been found, but Watt jr declined on the grounds of having recently lost a significant sum by "imprudently" acting as surety for a

\footnotetext{
${ }^{129}$ [Davy], "Lines: Descriptive of feelings produced by a visit to the place where the first nineteen years of $\mathrm{my}$ life were spent, on a stormy day, after an absence of thirteen months," Annual Anthology 2 (1800): 293-6, 295. ${ }^{130}$ Davy to James Webbe Tobin, 21 March 1800, YUL OSB MS file 4203.

${ }^{131}$ RI MS HD/20/B, 122. Davy, Researches, Chemical and Philosophical, 478.

132 Beddoes to Robinson Boulton, November 1799, LoB MS 3782/13/8/22.

${ }^{133}$ Gregory Watt to Davy, 5 June 1800, RI MS HD/26/G/5.

134 Thomas Frankland to James Edward Smith, 18 November 1799, Linnean Society MS JES/COR/15/6.

135 James Watt sr to Joseph Black, 22 November 1799, Black, vol. 2, 829.

136 Beddoes to Davies Giddy, 2 December 1799, CRO MS DG/42/34; Beddoes to James Watt jr, 5 December 1799, LoB MS 3219/6/2/B/75.
} 
friend who had failed and therefore did not have any spare funds. ${ }^{137}$ This was yet another idea associated with Beddoes's group in Bristol that did not succeed. ${ }^{138}$

Davy spent less than a week in Bristol before leaving in early December for his first visit to London which lasted for a week or so. Quite what took him there is not entirely clear, but it may have been to find a publisher for his proposed Researches. He met up with Coleridge, who showed Davy the current draft of his poem "Christabel", much delighting him. ${ }^{139}$ Coleridge and Davy also called on the radical writer William Godwin (1756-1836) at his home in the Polygon, Somers Town, on 4 December 1799. Judging by Godwin's diary he had only met Coleridge once before, Southey a few times, and Cottle and Beddoes once during a visit to Bristol in March 1798. Such contacts were clearly sufficient to justify the visit, and on the 7th Coleridge and Davy with James Webbe Tobin dined with Godwin. Two days later they met Godwin again, this time at a dinner given by the surgeon Anthony Carlisle (1768-1840). During these three meetings Davy, at least according to Coleridge, impressed Godwin enormously.

Following Davy's departure for Bristol, Coleridge began negotiations with Longman to publish a two-volume work by Davy on his researches, to be printed by Biggs and Cottle, but nothing came of these discussions. ${ }^{140}$ Coleridge also continued to see a good deal of Godwin who thought Davy "the most extraordinary human Being ... he had ever met" ${ }^{141}$ However, Godwin believed that Davy was wasting "his vast Talents" on chemistry, a subject which Coleridge told Davy he then stoutly defended by telling Godwin of the poetical nature of chemistry ${ }^{142}$ - doubtless a view derived, at least partially, from knowing Davy as both a chemist and a poet.

During November and early December, little experimentation had been undertaken at the MPI and in a letter to Watt sr written on Davy's twenty-first birthday, Beddoes partly

\footnotetext{
137 James Watt jr to Beddoes, 9 December 1799, LoB MS 3219/6/7, 141.

138 Tim Fulford, Debbie Lee and Peter J. Kitson, Literature, Science and Exploration in the Romantic Era: Bodies of Knowledge (Cambridge: Cambridge University Press, 2004), 216-17.

${ }^{139}$ Coleridge to Southey, 19 December 1799, Coleridge Letters, vol. 1, 547-50.

${ }^{140}$ Coleridge to Davy, 1 January 1800, Coleridge Letters, vol. 1, 556-7. Coleridge to Southey, 24 December 1799, Coleridge Letters, vol. 1, 551-3 noted that he had dined with Longman day before.

${ }^{141}$ Coleridge to Tom Wedgwood, 2 January 1800, Coleridge Letters, vol. 1, 558-60.

142 Coleridge to Davy, 1 January 1800, Coleridge Letters, vol. 1, 556-7.
} 
placed the blame for this on Davy's absences. ${ }^{143}$ However, once back in Bristol Davy resumed experimentation and on 23 December briefly recorded in his notebook, presumably while still suffering a hangover: "I breathed after a terrible drunken fit a large quantity of gas 2 bags \& two bags of oxygen it made me sick". ${ }^{144}$ In his Researches he went into more detail writing that starting at four in the afternoon he drank a bottle of wine in less than eight minutes and soon became insensible, a state that lasted for more than two hours, waking to "head-ache and painful nausea" which continued even after vomiting. He then inhaled five quarts of nitrous oxide which had no effect (he attributed this to it being impure) followed by twelve quarts of oxygen, which likewise did not affect him. Finally, he inhaled seven quarts of pure nitrous oxide which cured the headache and he slept soundly during the night. "This experiment", he concluded, "proved that debility from intoxication was not increased by excitement from nitrous oxide". ${ }^{145}$ I suppose that must have been some sort of comfort.

The other experiment undertaken during the Christmas period used the sedan chair breathing box that Watt sr designed following his visit to Clifton and then constructed by Beddoes $^{146}$ who first used it on 21 December. ${ }^{147}$ On Boxing Day, Davy, with Kinglake's supervision, spent an hour and a quarter in the box measuring various physiological phenomena followed by another period of extended inhalation. ${ }^{148} \mathrm{He}$ emerged telling Kinglake that "nothing existed but thoughts". ${ }^{149}$

\section{Publication}

On that day Davy also wrote detailed notes describing experiments conducted over Christmas which formed the basis for the fourth and final section of his Researches on the

\footnotetext{
143 Beddoes to James Watt sr, 17 December 1799, LoB MS 3219/4/41/7.

${ }^{144}$ RI MS HD/20/B, p.95. See also his longer account in RI MS HD/20/B, 126-9.

145 Davy, Researches, Chemical and Philosophical, 481-4 and the draft of this passage in RI MS HD/20/B, 126-9. Cottle, Early Recollections, vol. 2, 35 gives an account of the incident, but he could have quite easily derived it from Davy's published version without being present.

${ }^{146}$ Beddoes to James Watt sr, 17 December 1799, LoB MS 3219/4/41/7.

${ }^{147}$ Beddoes's note on Josiah Wedgwood to James Watt sr, 21 December 1799, LoB MS 3219/4/41/44.

148 Davy, Researches, Chemical and Philosophical, 485-9; RI MS HD/20/B, 129-36.

${ }^{149}$ RI MS HD/20/B, 134. See also Davy, Researches, Chemical and Philosophical, 489.
} 
"Respiration of Nitrous Oxide" though whether the previous three sections were already finished is not known. ${ }^{150}$ Early in the new year Davy realising that it would be at least two months before anything could be published, wrote a long letter to Nicholson's Journal. The first half provided an account of how best to make respirable nitrous oxide - something Beddoes had not provided in his Notice - concluding with an outline structure of what would become Researches. The second half of the letter dealt with his other investigations. ${ }^{151}$ At some point in February or early March, Beddoes wrote to the Philosophical Magazine, reporting that he and Davy were writing a book, already in the press, on the gas and its effects. ${ }^{152}$ While this might refer to the fifteen pages written by Beddoes mostly describing further case histories included towards the end of Researches, ${ }^{153}$ the tone of Beddoes's letter does suggest something more substantial, but that never happened. This could be interpreted as perhaps suggesting some kind of falling out between them or yet another project that was imagined but never completed. Southey, who saw Davy frequently at this time before departing for Lisbon at the end of April, commented that the "book upon the nitrous oxyd will form an epoch in the science". ${ }^{154}$ Southey's move to Portugal, among other things, put the possibility of a third volume of The Annual Anthology in doubt, and so, probably during March, Davy and Danvers agreed to produce it, ${ }^{155}$ but it too never materialised. Yet another of the large number of publishing projects, both scientific and literary, that were imagined by members of Beddoes's group that did not come to fruition. More positively it illustrates fecundity of scientific and literary activities in Bristol at the time, as well as the idealism and ambition of the people involved.

At some point Davy's negotiations with Longman for the publication of Researches fell through, but at the end of February the radical publisher Joseph Johnson (1738-1809), with whom Beddoes had published throughout the 1790s, including all five parts of

\footnotetext{
${ }^{150}$ RI MS HD/20/B, 107-37.

151 Davy, "Letter ... on Gaseous Oxide of Azote, on certain Facts relating to Heat and Light, and on the Discovery of the Decomposition of the Carbonate and Sulphate of Ammoniac," Nicholson's Journal 3 (1800): 515-18.

152 "Gaseous Oxyd of Azot", Philosophical Magazine 6 (1800): 189-91 (189).

153 Beddoes, "Abstracts from Additional Details. - Observations on the Effects of Nitrous Oxide," in Davy, Researches, Chemical and Philosophical, 533-48.

154 Southey to William Taylor, 20 February 1800, CLRS.

155 Southey to Coleridge, 1 April 1800, CLRS.
} 
Considerations, offered Davy $£ 70$ for his "Physiological Expers. investig" ${ }^{n 156}$ which Davy thought liberal for an unseen text. ${ }^{157}$ As with Beddoes's texts, Johnson would take the financial risk while the book would be printed in Bristol by Biggs and Cottle. As with other texts printed by Biggs and Cottle, early sheets were printed off while Davy continued writing the final sections into the summer. ${ }^{158} \mathrm{He}$ could thus continue experimentation both on himself and others and publish the results in Researches as the early parts went through the press. For instance, he inhaled six quarts on both 23 and 24 March 1800, on the latter occasion with Southey present, ${ }^{159}$ while on the 30th Southey's friend, the civil servant Grosvenor Bedford (1773-1839), provided Davy with an account of his pleasurable experiences in breathing six quarts, ${ }^{160}$ as did another civil servant John Rickman (1771-1840) at some point in either February or March. ${ }^{161}$

Despite Researches now nearing completion (Beddoes reported that it would ready during the week beginning 9 June ${ }^{162}$ ), Davy nevertheless continued experimentation into June publishing the resulting accounts towards the end of the book ${ }^{163}$ and dating the introduction the 25th. Copies of Researches, priced at half a guinea (10s $6 \mathrm{~d})$ and running to nearly six hundred pages, which Beddoes esteemed "a great effort of genius", were available by mid-July when Davy sent Gregory Watt a copy. ${ }^{164}$ During August it was advertised in The Times (seen by Bentham) and listed briefly in Nicholson's Journal. ${ }^{165}$

\section{Davy, Coleridge and Lyrical Ballads}

\footnotetext{
156 Joseph Johnson to Davy, 27 February 1800, in The Joseph Johnson Letterbook, ed. John Bugg (Oxford: Oxford University Press, 2016), 66-7.

157 Davy to James Webbe Tobin, 21 March 1800, YUL OSB MS file 4203.

158 Davy to Davies Giddy, 3 July 1800, Paris, vol. 1, 85-8.

${ }^{159} \mathrm{RI}$ MS HD/20/B, 151-2.

${ }^{160}$ Grosvenor Bedford, 30 March 1800 in Davy Researches, Chemical and Philosophical, 528-9.

161 John Rickman, nd in Davy, Researches, Chemical and Philosophical, 526-7. For Rickman's visit to Bristol, see Southey to Thomas Southey, 23 March 1800, CLRS.

162 Beddoes to Alexander Tilloch, 8 June 1800, Philosophical Magazine, 7 (1800): 96.

163 Davy, Researches, Chemical and Philosophical, 530-2 and 494 described experiments conducted on 1 and 5 June 1800 respectively.

${ }^{164}$ Beddoes to Robinson Boulton, 15 July 1800, LoB MS 3782/13/8/24.

165 The Times, 26 August 1800, 2a. Jeremy Bentham to Peter Roget, 4 September 1800, Bentham, Correspondence, vol. 6, 346-9. Nicholson's Journal 4 (1800): 240.
} 
During May, with Davy still writing Researches, Coleridge returned from visiting Wordsworth at Grasmere and spent some time in Bristol before going to Nether Stowey to house hunt. ${ }^{166}$ In Bristol Coleridge "was much with Davy" and in a faint echo of his and Southey's earlier Rousseau-inspired pantisocratic ideas, Coleridge suggested that if he failed to find a suitable house in Somerset that Godwin, Davy and Wordsworth should all settle in the Lake District, assuring Godwin that in those circumstances, Davy would join them in the autumn. ${ }^{167}$ This seems to have been wishful thinking on Coleridge's part since Davy told him, after his failure to find a suitable Somerset house, of his sorrow that "your resolution is fixed on the northern dwelling" suggesting that he had no intention of joining him. ${ }^{168}$ While in Bristol Coleridge inhaled nitrous oxide on a further three occasions, although it is possible that one or more of these sessions might have occurred when he returned briefly to Bristol in midJune where he again "spent much time" with Davy. ${ }^{169}$ Whenever precisely those experiences occurred Coleridge described them, along with his October 1799 respirations, in a note published in Davy's Researches. ${ }^{170}$ Following, his brief visit June visit to Bristol, Coleridge returned to Wordsworth, remaining in the North of England until November 1801. ${ }^{171}$

While in Bristol, Coleridge read the manuscript of at least one of Wordsworth's new poems, "The Brothers", to Davy ${ }^{172}$ and left some other manuscript poems with him. ${ }^{173}$ Writing from Ambleside to Southey just before Easter, Coleridge told him that "Wordsworth publishes a second Volume of Lyrical Ballads". ${ }^{174}$ By the beginning of June Wordsworth had decided, since Lyrical Ballads was performing better than expected - indeed selling out, ${ }^{175}$

\footnotetext{
${ }^{166}$ Coleridge to Josiah Wedgwood, 12 June 1800, Coleridge Letters, vol. 1, 591.

167 Coleridge to Godwin, 21 May 1800, Coleridge Letters, vol. 1, 587-9. At the start of the year Coleridge had proposed something similar to Davy, including Tobin, Wordsworth and Southey. Coleridge to Davy, 1 January 1800, Coleridge Letters, vol. 1, 556-7.

168 Davy to Coleridge, 8 and 9 June 1800, RI MS HD/27/C/3.

${ }^{169}$ Coleridge to Josiah Wedgwood, 12 June 1800, Coleridge Letters, vol. 1, 591. Davy to Davies Giddy, 3 July 1800 , Paris, vol. 1, 85-8. Coleridge's visit could have been no longer than two or, at most, three days.

170 Coleridge, [May or June 1800] in Davy Researches, Chemical and Philosophical, 516-18.

${ }^{171}$ Coleridge to Godwin, 19 November 1801, Coleridge Letters, vol. 2, 775.

172 Coleridge to Davy, 25 July 1800, Coleridge Letters, vol. 1, 611-12.

173 Wordsworth to Davy, 29 July 1800, Wordsworth Letters, 289-90.

174 Coleridge to Southey, 10 April 1800, Coleridge Letters, vol. 1, 585-6.

175 Dorothy Wordsworth to Jane Marshall, 10 and 12 September 1800, Wordsworth Letters, 293-301.
} 
to produce a second edition as well as a second volume. ${ }^{176}$ It would be published in London by Longman, but printed in Bristol by Biggs and Co. Coleridge joined Wordsworth at Grasmere for three and a half weeks beginning at the end of June to work intensively on the second volume, although, judging from their letters, both men were unwell during this period; indeed, Coleridge sent details of Wordsworth's symptoms to Beddoes, though his prescription made Wordsworth's "countenance darken" ${ }^{177}$ With both Wordsworth and Coleridge in the Lake District and Southey in Lisbon, who else in Bristol, other than Davy, could be trusted to see the volumes through the press? Davy possessed the necessary experience of printing texts and Coleridge at least had confidence in his poetical sensibility. On 16 July, Coleridge wrote Davy a long letter telling him that once he had "disembrangled my affairs ... I shall attack chemistry, like a Shark" and asking for a copy of Researches. Towards the end Coleridge repeated the invitation to Davy to join him at Keswick in the fall and remarked that he had "read the little chemist's pocket book twice over". Then, right at the end, almost as a throw-away line, Coleridge asked "Will you be so kind as just to look over the sheets of the lyrical Ballads?"178

Such an off the cuff reference suggests Davy's pre-existing familiarity with the plan to publish Lyrical Ballads. It does not necessarily indicate that his already having the manuscripts of some of the poems meant that Coleridge had previously asked him to supervise the printing. It may, however, suggest that giving Davy the texts was one way of drawing him further into Coleridge's circle-to form a new coterie as Tim Fulford might put it ${ }^{179}$ - and the invitation to move to the Lakes would also further this. Unfortunately, Davy's reply has not survived; only Coleridge's response saying he had forwarded the letter to Wordsworth, adding that the poems already in Davy's possession should not be given to

\footnotetext{
${ }^{176}$ William Wordsworth to Richard Wordsworth, 8 June 1800, Wordsworth Letters, 283-4.

177 Coleridge to Davy, 16 July 1800 and 9 October 1800, Coleridge Letters, vol. 1, 604-7 and 630-4 respectively. What Beddoes prescribed is not recorded.

${ }^{178}$ Coleridge to Davy, 16 July 1800, Coleridge Letters, vol. 1, 604-7. The book mentioned was James Parkinson, The Chemical Pocket-Book, or Memoranda Chemica; arranged in a Compendium of Chemistry, according to the latest discoveries, with Bergman's table of single elective attraction, as improved by Dr. G. Pearson. Calculated, as well for the occasional reference of the Professional Student, as to supply others with a General Knowledge of Chemistry (London: Symonds, Murray and Highley, Callow, Coxe, Arch, and Cuthell, 1800). This contained quite few references to Davy's work.

${ }^{179}$ Fulford.
} 
Biggs and Cottle. ${ }^{180}$ Furthermore, unless this was yet another example of Coleridge's wishful thinking, Davy had indicated that he would arrive in Keswick in early September, or at least that is what Coleridge told J.W. Tobin to encourage him to visit also with the prospect of chemistry. ${ }^{181}$ Wordsworth received Davy's letter to Coleridge on 28 July ${ }^{182}$ and the following day wrote directly to Davy. Concerned that because he had not looked over them they might contain errors, Wordsworth reinforced Coleridge's request not to give Biggs and Cottle the poems already in his possession. In their place, Wordsworth sent Davy the manuscripts of the first four poems for the second volume of Lyrical Ballads, including the opening verses of "The Brothers". He asked him to correct "the punctuation a business which I am ashamed to say I am no adept" and look over the proofs as they were printed. Finally, he wrote that he would be sending the "Preface" to the first volume "in a few days". ${ }^{183}$ In early August he sent a further sheet of poems to Biggs and Cottle reminding them that the proofs should be given to Davy. ${ }^{184}$ During the second week of August Wordsworth dispatched further manuscript poems for Lyrical Ballads to Bristol, the checking and proofing of which would have also occupied a significant proportion of Davy's time. ${ }^{185}$ Indeed, Coleridge concluded in a letter to Tobin that “From Davy's long silence I augured that he was doing something for me", but nevertheless expressed his disappointment that Davy had not come to Keswick.

In mid-September Wordsworth sent another set of poems to Biggs and Cottle, together with instructions to place them before Coleridge's "Christabel" even if the type had already been set, adding that he would send the "Preface" in the next four days. ${ }^{186}$ Three weeks later following a short visit by Coleridge to Grasmere, Wordsworth instructed Biggs and Cottle to remove "Christabel" from the volume, adding that he would reimburse any

\footnotetext{
180 Coleridge to Davy, 25 July 1800, Coleridge Letters, vol. 1, 611-12.

${ }^{181}$ Coleridge to James Webbe Tobin, 25 July 1800, Coleridge Letters, vol. 1, 612-14.

182 Noted in Dorothy Wordsworth, Diary, 28 July 1800, in Dorothy Wordsworth: The Grasmere and Alfoxden Journals, ed. Pamela Woof (Oxford: Oxford University Press, 2002), 15.

${ }^{183}$ Wordsworth to Davy, 29 July 1800, Wordsworth Letters, 289-90.

184 Wordsworth to Biggs and Cottle, 4 August 1800, Wordsworth Letters, 291.

${ }^{185}$ Wordsworth to Biggs and Cottle, c13 and c13 August 1800, Wordsworth Letters, 291-2 and 292-3 respectively.

${ }^{186}$ Wordsworth to Biggs and Cottle, 15 September 1800, Wordsworth Letters, 302.
} 
cost already incurred, ${ }^{187}$ although it is not clear if it had yet been set. As Johnston has pointed out this entailed Wordsworth producing extra poems to fill the vacated space and, of course, this would require further time. ${ }^{188}$ The now necessary delay in publication seems to have changed how the volume would be handled. It is quite evident that the initial intention had been to produce the volume as quickly as possible, hence the need for Davy's involvement. But with the delay and thus more time for letters to pass between Bristol and the Lake District, Davy's role seems to have diminished. By December, Biggs and Cottle were sending printed proofs to Coleridge and Wordsworth which the latter was correcting, including the placement of commas with precise page references - just the sort of thing he initially asked Davy to undertake. ${ }^{189}$

Davy's intimate acquaintance with Wordsworth's poetry seems to have led him towards a degree of imitation. Wordsworth's visit to the Wye Valley in 1798 inspired his poem "Tintern Abbey" and probably in early October 1800, Davy with King and Danvers travelled up the Valley for four days, spending three hours by the light of the full moon exploring the Abbey. ${ }^{190}$ The party went as far north as Monmouth, Davy collecting air for chemical analysis on the way including at the mouth of the Severn while returning to Bristol during a stormy crossing. ${ }^{191}$ It may well have been on this excursion that Davy wrote a couple of poems possibly with the projected third volume of Annual Anthology in mind. He wrote one into various blank spaces in his notebook and those pages do show signs of having been out of doors. Here Davy parodied one aspect of Wordsworth's style with a poem of seven four line stanzas exemplified by:

My cousin was a simple man

A simple man was He

His face was a hue of $\tan$

\footnotetext{
187 Wordsworth to Biggs and Cottle, 6 or 7 October 1800, Wordsworth Letters, 304-5.

${ }^{188}$ Kenneth Johnston, The Hidden Wordsworth: Poet, Lover, Rebel, Spy (New York: Norton, 1998), 743.

189 Wordsworth to Nathaniel Biggs, 19 December 1800, Wordsworth Letters, 311-12.

190 Davy to Davies Giddy, 20 October 1800, Paris, vol. 1, 108-11. Full moon fell on 2 October.

191 Ibid. and RI MS HD/20/C, p.53 for the analysis of the air sample from the mouth of the Severn.
} 


$$
\text { And sparkling was his eye }{ }^{192}
$$

The second poem that Davy may also have written around this time, entitled "Written after Recovery from a Dangerous IIIness", he sent to Coleridge for comment. Possibly composed following a severe ague attack that Beddoes suffered during September, ${ }^{193}$ the text that survives comes from after Davy's own very serious illness at the end of 1807 when Coleridge visited him for a while. ${ }^{194}$ Coleridge's response to "Recovery" came a couple of days after he returned to Keswick from his short visit to Grasmere, where, he told Davy that Wordsworth was "fearful, you have been much teized by the Printers on his account". Coleridge's comments on Davy's poem were generally positive, pointing out that it conveyed "strict philosophical Truths, i.e. scientifically philosophic" ${ }^{195}$ Coleridge thus displayed the same opinions that he expressed to Davy at the start of the year about the relationship between chemistry and poetry.

Despite illness, Davy continued writing and experimenting as evinced by his beginning a new notebook towards the end of November. ${ }^{196}$ He wrote to Coleridge then saying he had "made some important galvanic discoveries which seem to lead to the door of the temple of the mysterious god of Life", 197 adding that he would soon publish his work, but that never happened. Davy also regretted that "Christabel" would no longer be published in Lyrical Ballads, which is the only existing direct evidence of his continuing significant involvement with the publication at this time. Coleridge, also ill during November, did not respond to Davy's galvanic work, but did ask him to send him any sheets of "Christabel" already printed. ${ }^{198}$ Finally, on 18 December, a week before Christmas,

\footnotetext{
192 RI MS HD/20/C, p.44. The other stanzas are on 46 and 52. Fullmer, 137-8, and Jenkins, "Humphry Davy," $141-2$, published all seven stanzas. Both these and other critics read this poem as a parody of Wordsworth rather than of anyone else.

193 Thomas Johnes to James Edward Smith, 29 September 1800, Linnean Society MS JES/COR/16/65. Beddoes's illness is also referred to in Coleridge to Davy, 9 October 1800, Coleridge Letters, vol. 1, 630-4 and Davies Giddy to Josiah Wedgwood, 6 November 1800, WM MS E2-1558.

194 Coleridge to Dorothy Wordsworth, 24 November 1807 and Coleridge to Southey, 14 December 1807, Coleridge Letters, vol. 3, 37-9 and 41-3 respectively. The text of the poem is in Davy, Memoirs of Humphry Davy, vol. 1, 390-2.

195 Coleridge to Davy, 9 October 1800, 9 October 1800, Coleridge Letters, vol. 1, 630-4.

${ }^{196} \mathrm{RI} \mathrm{MS} H \mathrm{HD} / 22 / \mathrm{B}$.

197 Davy to Coleridge, 26 November 1800, Morgan Library and Museum, Misc English Coleridge, MA 1857.

198 Coleridge to Davy, 2 December 1800, Coleridge Letters, vol. 1, 648-50.
} 
Wordsworth sent, in three letters, the concluding poems for Lyrical Ballads. ${ }^{199}$ Davy's involvement, at least to some extent, with the volume at the time can be inferred by his admiration, expressed in a letter to Coleridge, of "Michael". ${ }^{200}$ In dealing with these final sheets, he overlooked the omission of half of page 210 of "Michael". In a letter to Poole, Coleridge blamed the printers for the blunder, and his forbearance to mention Davy suggests again that his role in producing the volume had become limited as time went on. ${ }^{201}$ The two volumes finally became available in mid-January 1801 (with an $1800 \mathrm{imprint}$ ) when Wordsworth sent complimentary copies to various eminent individuals. ${ }^{202}$

\section{Chemistry in the Lakes}

Early in 1801, Coleridge concocted, with William Calvert (1770-1829), a friend of Wordsworth's, the idea of building a chemical laboratory as part of Calvert's new house in Keswick. Coleridge suggested, perhaps recollecting their time at Alfoxden when poetry had been at the centre of their activities, that he, Wordsworth and his sister Dorothy Wordsworth (1771-1855) would also live in the house and they would all study chemistry under Davy's tutelage thus forming a new coterie, but one devoted to chemistry. Although Coleridge thought that Wordsworth would be "strongly inclined to adopt the scheme" this was probably yet again wishful thinking, though he did add that he and Calvert would proceed without Wordsworth's participation. He asked Davy's advice on what books to acquire, the design of laboratory, the expense of the necessary apparatus (noting that Calvert already possessed an electro-static generator) and whether Davy would oversee their construction in Bristol. Coleridge clearly implied Calvert possessed significant wealth, but made no reference to any payment for Davy to move to the Lake District, so it is not clear whether Coleridge saw this as a long-term arrangement or based on Davy visiting occasionally. ${ }^{203}$

\footnotetext{
${ }^{199}$ Wordsworth to Biggs and Cottle, 18 December 1800, Wordsworth Letters, 306-8, 308, 308-9.

200 This letter has not been found but Davy's view of "Michael" is quoted back at him in Coleridge to Davy, 11 January 1801, Coleridge Letters, vol. 2, 662-4.

201 In Coleridge to Thomas Poole, 16 March 1801, Coleridge Letters, vol. 2, 706-8

202 For example, Wordsworth to Charles James Fox, 14 January 1801, Wordsworth Letters, 312-15. See also Coleridge to Thomas Poole, 19 January 1801, Coleridge Letters, vol. 2, 664-7.

${ }^{203}$ Coleridge to Davy, 3 February 1801, Coleridge Letters, vol. 2, 670-2.
} 
Whatever arrangement Coleridge envisioned, it did not come about. Davy, who for a few months, had been anxious to leave Bristol visited London during mid-February. There he was appointed assistant lecturer in chemistry at the recently founded Royal Institution. This new employment clearly meant that Davy could not accept Coleridge's invitation to join him, Calvert and possibly Wordsworth in establishing a chemical coterie in Keswick. Unfortunately, we do not have Davy's reply to Coleridge, only a letter written in mid-March from Coleridge to Poole mentioning Davy's Royal Institution appointment adding that he had "received a very affectionate Letter from him on the Occasion". ${ }^{204}$ It would seem that Coleridge made good on his intention to study chemistry, even if his scheme did not come off. He wrote to Davy early in May that he "had become a formidable chemist - having got by heart a prodigious quantity of terms \&c to which I attach some ideas". Indeed, he began deploying this learning in developing metaphors. Thus, when he heard from Tobin about Davy's Royal Institution lectures on galvanism, he told Davy “My motive muscles tingled \& contracted at the news, as if you had bared them \& were zincifying the life-mocking Fibres". ${ }^{205}$ Since Coleridge did not see Davy during the period of his galvanic experiments, it is clear that he had paid serious attention to published accounts of galvanism and/or now lost letters from Davy describing his work.

\section{Conclusion}

At the start of November 1800 Southey, from Lisbon, sent the manuscript of his poem "Thalaba the Destroyer" to Danvers asking for his and Davy's comments as quickly as possible so that the work could be sent to the press and he could be paid for it. ${ }^{206}$ Danvers and Davy both commented, and indeed Davy's suggested a plan for reorganising book twelve which Southey said he would adopt. ${ }^{207}$ Furthermore, Danvers with probably some help from the now very experienced Davy, saw "Thalaba" through Biggs and Cottle's press in Bristol for publication by Longman. ${ }^{208}$ The successful publication of this poem illustrates,

\footnotetext{
${ }^{204}$ Coleridge to Thomas Poole, 16 March 1801, Coleridge Letters, vol. 2, 706-8.

205 Coleridge to Davy, 4 May 1801, Coleridge Letters, vol. 2, 726-7.

${ }^{206}$ Southey to Charles Danvers, 6 November 1800, CLRS.

207 Southey to Charles Danvers, 20-24 January 1801, CLRS.

${ }^{208}$ See, for example, Southey to Charles Danvers, 17 February 1801, CLRS.
} 
along with Davy's Researches, two volumes of Southey's Annual Anthology and Wordsworth's Lyrical Ballads, that the group loosely centred on Beddoes's Medical Pneumatic Institution were able to create a key moment in English cultural history. But each of these productions (and others), for the contingent reasons I have identified, took far longer to produce than originally anticipated. Because of that the production of the texts in the print culture of Bristol was not straightforward. For example, the special place that Davy occupies in the history of science and of literature needs to be revised due to the time it took to print Lyrical Ballads. As the delays accumulated, it is clear that using the postal system Coleridge and Wordsworth, during the latter part of 1800, played a much greater role in instructing Biggs and Cottle about the text; Davy's role diminished accordingly and he became careless, evinced by missing lines from "Michael".

Furthermore, as this essay has illustrated, there were many false starts made by members of this creative group during this very short time-span: no later volumes of Beddoes's Contributions or Southey's Annual Anthology, no separate volume of poetry from Davy, no chemical laboratory in the Lakes, no Alderney Cow Therapy and so on. The process of creating that Romantic moment in Bristol was never straightforward, no one really had a clear idea of when an endpoint (if any) would be reached until publication. And that shows the centrality of printing in defining a new culture in both literature and science. 